\title{
PENGARUH THERMAL WALL TERHADAP KARAKTERISTIK HIDRODINAMIKA DAN KARAKTERISTIK SYNGAS PADA DUAL FLUIDIZED BED GASIFIER BERBABAHAN BAKAR TEMPURUNG KELAPA DENGAN SIMULASI BERBASIS CPFD
}

\author{
Nur Aklis \\ Mahasiswa Program Studi Doktor Teknik Mesin \\ Departemen Teknik Mesin dan Industri \\ Universitas Gadjah Mada \\ Email: nur.aklis@ums.ac.id \\ Tri Agung Rohmat \\ Departemen Teknik Mesin dan Industri \\ Universitas Gadjah Mada \\ triagung_rohmat@ugm.ac.id \\ Harwin Saptoadi \\ Departemen Teknik Mesin dan Industri \\ Universitas Gadjah Mada \\ harwins@ugm.ac.id
}

\begin{abstract}
ABSTRAK
Artikel ini membahas simulasi pengaruh temperatur dinding atau thermal wall atau (t.w) terhadap karakteristik hidrodinamika dan karakteristik syngas Dual fluidized bed gasifier (DFBG) dengan bahan bakar biomassa tempurung kelapa berbasis computational particle fluid dynamics (CPFD). Simulasi dilakukan dengan menggunakan software paket Barracuda VR 17.1.0. Uap dengan suhu $423 \mathrm{~K}$ dan tekanan $101325 \mathrm{~Pa}$ digunakan sebagai agen gasifikasi. Partikel yang digunakan berupa pasir silika dengan densitas $2650 \mathrm{~kg} / \mathrm{m}^{3}$ dan ukuran antara $180-600 \mu \mathrm{m}$. Ukuran tempurung kelapa $2-4 \mathrm{~mm}$. Parameter operasi DFBG meliputi kecepatan uap di gasifier $1,5 \mathrm{~m} / \mathrm{s}$, kecepatan udara di riser sebesar $10 \mathrm{~m} / \mathrm{s}$, kecepatan udara di L-valve sebesar $1,57 \mathrm{~m} / \mathrm{s}$ dan kecepatan uap di loop-seal sebesar $0,4 \mathrm{~m} / \mathrm{s}$ dan $0,5 \mathrm{~m} / \mathrm{s}$. Grid yang digunakan sejumlah 129.024 dan simulasi menggunkan 3 variasi thermal wall (t.w) masing-masing sebesar $873 \mathrm{~K}, 973 \mathrm{~K}$ dan $1073 \mathrm{~K}$. Dari hasil simulasi diketahui thermal wall berpengaruh terhadap karakteristik hidrodinamika yang dihasilkan simulasi dimana pada simulasi temperatur rendah $(\mathrm{t} . \mathrm{w}=873 \mathrm{~K})$ sirkulasi material bed tampak mengalami penumpukan di riser bagian bawah, hal ini tidak terjadi pada sirkulasi material bed yang dihasilkan oleh simulasi dengan t.w $=973 \mathrm{~K}$ dan $1073 \mathrm{~K}$. Komposisi dan distribusi spesies gas hasil gasifikasi yang dihasilkan simulasi dengan t.w yang berbeda-beda menunjukkan kecenderungan yang sama, dimana masing-masing variasi menghasilkan gas dengan komposisi yang didominasi $\mathrm{CO}$ dan $\mathrm{H}_{2}$. Pengaruh temperatur dinding terlihat pada naiknya komposisi dan yield masing-masing spesies gas., dimana kompoisisi gas naik 5,78 \% saat t.w dinaikkan dari $873 \mathrm{~K}$ menjadi $973 \mathrm{~K}$ dan naik 2,8 \% saat t.w naik menjadi1073 K. Yield gas naik 20,4\% saat t.w naik dari $873 \mathrm{~K}$ menjadi $973 \mathrm{~K}$, dan naik sebesar $17,5 \%$ saat t.w berubah dari $973 \mathrm{~K}$ menjadi $1073 \mathrm{~K}$.
\end{abstract}

Kata kunci: dual fluidized bed gasifier, tempurung kelapa, CPFD, syngas, thermal wall 


\begin{abstract}
This article presents the effect of the thermal wall $(t . w)$ on hydrodynamic characteristics and syngas characteristics of Dual Fluidized bed Gasifier (DFBG) with coconut shell as a fuel based on computational particle fluid dynamics (CPFD) simulation. The Simulations were carried out using the Barracuda VR 17.1.0 CPFD package software. Steam with a temperature of $423 \mathrm{~K}$ and a pressure of $101325 \mathrm{~Pa}$ was used as a gasification agent. Silica sand with a density of $2650 \mathrm{~kg} / \mathrm{m} 3$ and size between 180 - $600 \mu \mathrm{m}$ was used as bed material. The size of the coconut shell is 2-4 mm. $D F B G$ was operated with operating parameters that include steam velocity in the gasifier of $1.5 \mathrm{~m}$ $/ s$, air velocity in the riser of $10 \mathrm{~m} / \mathrm{s}$, air velocity in the L-valve of $1.57 \mathrm{~m} / \mathrm{s}$, and velocity of steam in the loop-seal of $0.4 \mathrm{~m} / \mathrm{s}$ and $0.5 \mathrm{~m} / \mathrm{s}$. The grid used was 129,024 and the simulation was carried out for $120 \mathrm{~s}$. The simulation uses 3 variations of the thermal wall (t.w) of $873 \mathrm{~K}, 973 \mathrm{~K}$, and 1073 $K$. The results of the simulation show that the wall temperature affects the hydrodynamic characteristics produced by the simulation where at low temperature $(t w=873 \mathrm{~K}$ ) the circulation of the bed material appears to be accumulated at the bottom of the riser, this does not occur in the circulation of the bed material produced by the simulation with $t . w=973 \mathrm{~K}$ and $1073 \mathrm{~K}$. The composition and distribution of the syngas resulting from the simulation with different thermal wall shows the same tendency, where each variation produces gas with a composition dominated by $\mathrm{CO}$ and $\mathrm{H}_{2}$. The effect of wthermal wall is seen in the increase in the composition and yield of each gas species. The effect of wall temperature is seen in the increase in the composition and yield of each gas species, where the gas composition increases by $5.78 \%$ when t.w increases from $873 \mathrm{~K}$ to $973 \mathrm{~K}$ and increases by $2.8 \%$ when t.w changes to $1073 \mathrm{~K}$. The gas yield increases by 20 , $4 \%$ when t.w increases from $873 \mathrm{~K}$ to $973 \mathrm{~K}$, and increases by $17.5 \%$ when t.w changes to $1073 \mathrm{~K}$,
\end{abstract}

Keywords: dual fluidized bed gasifier, coconut shell, CPFD, syngas, thermal wall

\title{
1.3 PENDAHULUAN
}

Saat ini bahan bakar minyak (BBM) masih menjadi sumber energi utama sektor otomotif. Tercatat pada tahun 2014 97, 2 \% sektor otomotif menggunakan minyak sebagai bahan bakarnya. Data dari Badan Pusat Statistik (BPS) menunjukkan setiap tahunnya produksi kendaraan selalu meningkat [1], sebaliknya jumlah produksi BBM setiap tahunnya mengalami penurunan sehingga impor BBM Indonesia setiap tahun selalu meningkat. Ketergantungan terhadap impor BBM menyebabkan persoalan pada ketahanan energi sehingga diperlukan alternatif untuk sumber energi baru pengganti BBM untuk kebutuahan transportasi.

Biomassa memiliki potensi untuk dikonversi menjadi bahan bakar otomotif melalui beberapa cara. Salah satunya adalah dengan model proses Fischer-Tropsch (F-T). Fischer-Tropsch adalah serangkaian proses reaksi kimia yang mengkonversi karbon monoksida dan hidrogen menjadi bahan bakar hidrokarbon cair. Tahapan Proses F-T meliputi gasifikasi, pengkondisian dan pembersihan gas, tahap sintesa syngas di reaktor (F-T) dan tahap upgrade produk [2].

Gasifikasi merupakan tahap penting dalam proses konversi biomassa menjadi BTL-fuels. Gas hasil gasifikasi berperan sebagai bahan baku proses F-T. Gasifikasi adalah konversi termo-kimia dari bahan bakar padat seperti; batu bara, minyak bumi, coke, plastik, biomassa dan limbah padat menjadi gas yang bernilai guna melalui oksidasi parsial pada suhu tinggi dengan menggunakan agen gasifikasi. Agar dapat digunakan sebagai bahan baku proses F-T gas yang dihasil gasifikasi memiliki syarat tertentu. Ail\&Dasappa [3] menjelaskan untuk dapat dijadikan bahan bakar Proses F-T, gas harus memiliki syarat tertentu salah satunya adalah perbandingan $\mathrm{H}_{2} / \mathrm{CO}$ berada pada kisaran $0,6-2,5$.

Salah satu biomassa yang memiliki potensi untuk dimanfaatkan menjadi sebagai bahan bakar gasifikasi adalah limbah tempurung kelapa. Beberapa peneliti telah memanfaatkan tempurung kelapa untuk dikonversi menjadi gas dengan desain reaktor updraft, down draft dan fluidized bed [4], [5], [6] [7]. Hasil penelitian menunjukkan bahwa prosentase combustible gas yang dihasilkan dan $\mathrm{H}_{2} / \mathrm{CO}$ masih rendah. Salah satu langkah yang dapat dilakukan agar gas hasil gasifikasi memiliki kualitas gas yang dapat 
digunakan sebagai bahan bakar proses F-T adalah dengan penggunaan teknologi gasifikasi dual fluidized bed gasifier (DFBG).

Prinsip kerja DFBG dapat dijelaskan pada gambar 2. Reaktor fluidisasi dibagi menjadi 2 daerah: daerah gasifikasi dan daerah pembakaran. Sebagaimana dalam Gambar 2 bahan bakar padat dikonversi menjadi gas di reaktor gasifikasi. Arang yang tersisa di proses gasifikasi bersama dengan pasir akan mengalir ke reaktor pembakaran. Di reaktor pembakaran, arang bertemu dengan udara sehingga terjadi reaksi pembakaran yang menghasilkan kalor dan flue gas. Kalor tersebut diserap oleh pasir. Pasir dengan temperatur tinggi akan bersirkulasi kembali ke gasifier untuk mensuplai kebutuhan energi reaksi endotermis gasifikasi. Flue gas hasil pembakaran keluar dari sistem.

Penelitian eksperimen pengembangan dual fluidized bed gasifier (DFBG) telah dilakukan oleh beberapa peneliti. Penelitian eksperimen secara garis besar dilakukan dalam dua tahapan yaitu penelitian dengan pengujian cold flow model dan penelitian performa. Penelitian pengujian dingin atau cold model flow [8], [9], [10] yang bertujuan untuk mengetahui karakteristik hidrodinamika DFBG dan uji performa gasifier, [11], [12], [13]. Studi yang dilakukan telah menunjukkan keunggulan DFBG, namun metode ini memiliki keterbatasan dalam investigasi karakteristik dan fenomena yang terjadi pada saat DFBG beroperasi. Di samping itu untuk mendapatkan hasil yang optimum, dalam studi eksperimen proses trial and error membutuhkan sumber daya yang besar.
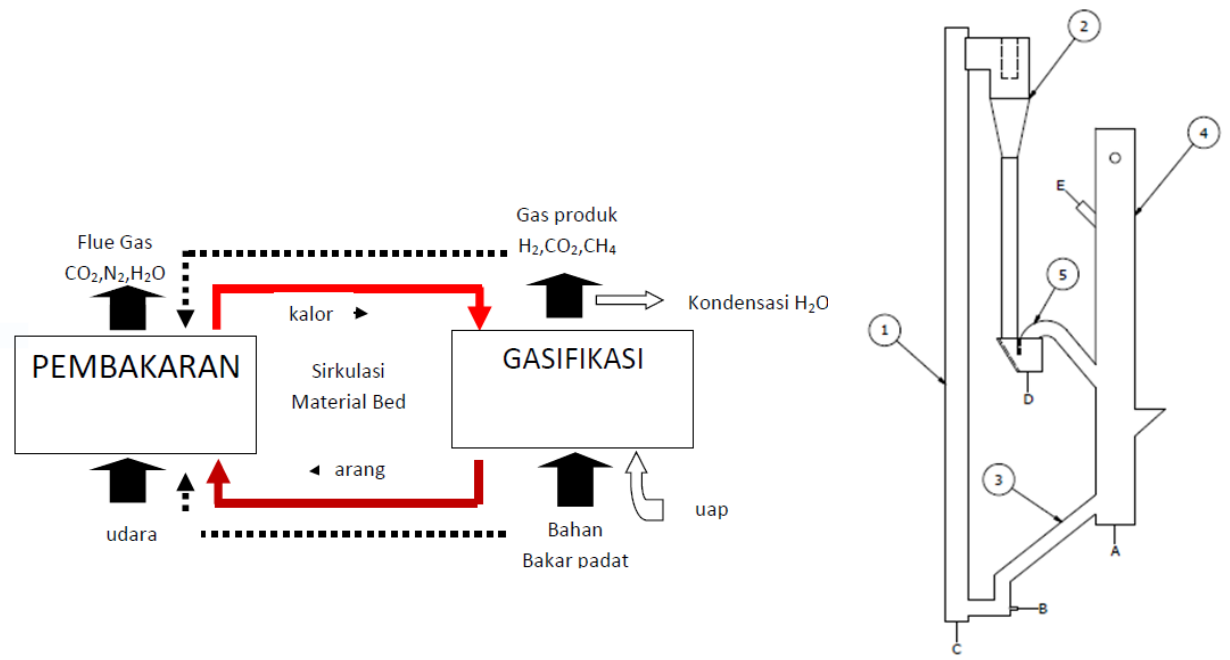

Gambar 2. Prinsip Kerja Dual Fluidized Bed Gasifier[14],[15]

Untuk memahami kompleksitas karakteristik dan fenomena dalam DFBG, beberapa peneliti melakukan penelitian dengan pemodelan dan simulasi. Studi tentang DFBG dengan metode simulasi telah dilakukan beberapa peneliti dengan beberapa model simulasi. Doherty et. al melakukan pemodelan DFBG berbasis Gibs free energy minimisation, nol-dimensi menggunakan software Aspen Plus. Hasil simulasi menunjukkan temperatur gasifikasi berpengaruh signifikan terhadap komposisi syngas, LHV syngas dan CGE, sedangkan kandungan moisture content berpengaruh signifikan terhadap CGE, STBR berpengaruh signifikan terhadap LHV syngas. Air-fuel ratio tidak berpengaruh signifikan terhadap komposisi syngas. Temperatur udara dan temperatur uap tidak berpengaruh signifikan terhadap syngas, LHV dan CGE. Meskipun telah divalidasi dengan data eksperimen yang menghasilkan kesesuaian dengan data eksperimen, namun simulasi ini dilakukan pada kondisi steadi dan belum melibatkan persamaan hidrodinamika gas dan partikel [16]. Shen et.al melakukan simulasi DFBG interconnected fluidized bed dengan menggunakan Aspen Plus. Simulasi dilakukan untuk mengetahui pengaruh temperatur gasifikasi dan perbandingan uap dan biomassa terhadap komposisi $\mathrm{H}_{2}$ yang dihasilkan. Hasil simulasi menunjukkan temperatur gasifikasi optimum diantara 750 sampai $800{ }^{\circ} \mathrm{C}$, temeperatur pembakaran $920{ }^{\circ} \mathrm{C}$ dan perbandingan uap/biomassa diantara 0,6 sampai 0,7[17]. Yan melakukan simulasi DFBG dengan menggabungkan persamaan kinetika 
dan persamaan hidrodinamika. Model diasumsikan sebagai proses satu dimensi dan steady state. Simulasi dilakukan dengan software Aspen plus yang dihubungkan dengan FORTRAN. Dari simulasi didapatkan hasil bahwa laju aliran biomassa, perbandingan uap dan biomassa, dan laju sirkulasi pasir berpengaruh terhadap komposisi gas yang dihasilkan. Walaupun sudah mampu menunjukkan hasil yang sesuai dengan eksperimen, fenomena yang terjadi di DFBG cenderung lebih rumit dan kompleks sehingga diperlukan model yang mampu menggambarkan karakteristik tiga dimensi DFBG baik karakteristik hidrodinamika, temperatur sistem dan maupun karakteristik gas yang dihasilkan[18].

Untuk mendapatkan gambaran lebih detail karakteristik hidrodinamika sekaligus komposisi dan distribusi hasil gas di DFBG, beberapa peneliti menggunakan model simulasi berbasis computational fluid dynamics (CFD) berbasis Multiphase Particle-In-Cell (MP-PIC). MP-IC adalah model yang berbasis Eulerian-Lagrangian dengan memetakan partikel yang memiliki kesamaan properti dalam satu parcel. Saat masuk ke grid parcel diperlakukan sebagai kontinum sebagaimana sifat fluida dan keluar dari grid parcel dikembalikan lagi sebagai partikel tunggal [19]. Pertama kali diperkenalkan oleh Andrews dan O'Rourke (1996), metode MP-IC merupakan pengembangan dari metode stochastic particle KIVA code [20].

Kraft et. al melakuan simulasi cold flow model tentang pengaruh drag model terhadap pressure dan recirculating rate dengan menggunakan drag laws energy-minimization multiscale (EMMS), Ganser, Turton-Levenspiel, Wen-Yu/Ergun. Hasil simulasi dibandingkan dengan hasil eksperimen. Dari empat drag laws model didapatkan hasil perbedaan yang signifikan anatara hasil simulasi dan eksperimen, walupun demikian Ganser cocok untuk mensimulasikan recirculating rate, sedang EMMS cocok untuk mensimulasikan tekanan [21].

Liu, et. al melakukan simulasi cold flow model dengan CPFD. Pengaruh parameter operasi meliputi suplai udara di riser, suplai uap terhadap laju sirkulasi pasir. Terdapat 3 buah air suplay di riser, dimana 1 dan 2 berada di riser bagian bawah, sedangkan air suplay berada pada tengah yang lebih tinggi dari air suplay 1 dan 2. Dari simulasi di dapatkan pengaruh kecepatan udara di air suplay bagian bawah (1 dan 2) berpengaruh lebih signifikan dibanding dengan kenaikan kecepatan udara di bagian atas (3). Hasil ini sesuai dengan yang didapatkan oleh data eksperimen yang didapat oleh Löffler et al. (2003) dan Kreuzeder et al. (2007)[22].

Liu et.al [23] melakukan simulasi 3 dimensi DFBG pengaruh parameter simulasi meliputasi mesh resulution dan particel computational number dan karakteristik partikel berupa Particel Size Distribution (PSD) terhadap karakteritik hidrodinamik dan performa Biomass DFBG. Hasil simulasi parameter simulasi menunjukkan mesh relosution dan particel computational yang berbeda tidak berpengaruh signifikan terhadap komposisi syngas yang dihasilkan. Hasil simulasi komposisi gas dibandingkan dengan hasil eksperimen dan menunjukkan kecenderungan yang sama. Pengaruh dari perbedaaan drag model yang digunakan terhadap komposisi gas tidak signifikan. Hal ini disebabkan karena pengaruh drag model terhadap karakteristik hidrodinamiknya tidak signifikan. PSD memiliki pengaruh signifikan pada ketinggaian bawah tetapi pada bagian atas tidak berpengaruh.

Kraft et.al [24]melakukan simulasi DFBG skala industri di CHP plant at Güssing yang bertujuan utuk memvalidasi hasil eksperimen berbasis CPFD. Parameter simulasi yang digunakan meliputi circulating rate, visualisasi rezim fluidisasi dan pressure dop pada tiap bagain komponen, temperatur dalam sistem, komposisi gas yang dihasilkan dan karakteritik pencampuran partikel. Dari simulasi yang telah dilakukan didapatkan hasil bahwa temperature dan komposisi gas menunjukkan hasil yang sesuai dengan hasil eksperimen. Secara kuantitatif simulasi juga mampu menjelaskan rezim fluidisasi yang terjadi pada gasifier, reaktor pembakaran, loop-seal dan chute, tetapi untuk penggambaran karakteristik pencampuran partikel simulasi belum mencapai hasil yang optimum.

Paper ini membahas konversi biomassa tempurung kelapa menjadi syngas pada reaktor DFBG dengan dengan metode simulasi CPFD mengunakan software paket barracuda dengan beberapa variasi temperatur operasi. 


\section{METODE SIMULASI}

\subsection{Geometri Reaktor}

Model reaktor yang digunakan pada paper ini adalah model reaktor yang menyerupai instalasi dual fluidized bed gasifier yang ada di Laboratorium Konversi Energi Universitas Gadjah Mada. Geometri dan ukuran bagian pokok reaktor dapat dilihat pada Gambar 2. Sebagaimana yang tergambar di Gambar 2 (a) model DFBG terdiri dari 2 buah reaktor yaitu reaktor gasifikasi dengan ukuran diameter $200 \mathrm{~mm}$, tinggi $2000 \mathrm{~mm}$, dan riser sebagai reaktor pembakaran berdiameter 114 $\mathrm{mm}$ dan tinggi $3000 \mathrm{~mm}$. Kedua reaktor dihubungkan dengan katup non-mekanik berupa loop-seal yang menghubungkan reaktor bagian atas dan $L$-valve yang menghubungkan reaktor bagian bawah. Penggunaan katup non-mekanik bertujuan untuk mencegah terjadinya aliran gas dari reaktor pembakaran ke gasifier dan sebaliknya dari reaktor gasifikasi ke reaktor pembakaran. Siklon berfungi untuk memisahkan flue gas dengan pasir bertemperatur tinggi. Bahan bakar dimasukkan ke reaktor melalui feeder yang dipasang di gasifier.

Proses operasi DFBG dapat dijelaskan sebagaimana pada gambar 2 (b). Gambar 2 (b) menunjukkan kondisi awal operasi dimana gasifier, L-valve dan lop-seal diisi pasir sebagai material material. Pasir dipanaskan pada suhu tertentu. Uap sebagai agen gasifikasi dialirkan dari bawah gasifier dan pada tahapdan biomassa dimasukkan dari screw feeder. Biomassa akan tergasifikasi dan akan menghasilkan syngas yang mengalir ke atas keluar dari gasifier. Arang sisa proses gasifikasi mengalir bersama pasir ke riser dan akan bertemu dengan udara yang dialirkan dari bawah riser sehingga akan terjadi proses pembakaran. Kalor hasil proses pembakaran memanaskan pasir. Di siklon pasir yang bertemperatur tinggi terpisah dengan flue gas, dimana flue gas akan keluar dari siklon sedangkan pasir akan turun ke bawah masuk ke loop-seal yang selanjutnya bersirkulasi kembali ke gasifier untuk mensuplai kalor yang dibutuhkan proses endoterm gasifikasi.

Geometri reaktor didefinisikan sebagai domain komputasi dengan grid yang digunakan sejumlah 129.024 .

(a)

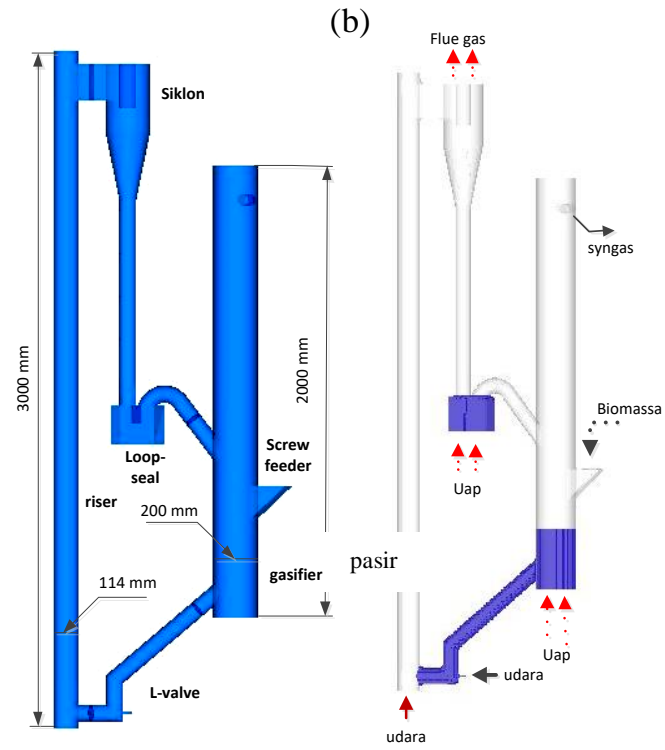

Gambar 2. (a) Geometri dan ukuran reaktor (b) Pemodelan operasi reaktor 


\subsection{Karakteristik Bahan bakar dan Partikel}

Simulasi yang dilakukan menggunakan bahan bakar tempurung kelapa dengan properti sebagaimana yang tertulis di Tabel 1. Pasir silika dipilih sebagai material bed, dimana properti pasir silika dapat dilihat pada Tabel 2.

\subsection{Persamaan Atur dan Persamaan Reaksi Kimia}

Pemodelan persamaan dual fluidized bed gasifier melibatkan 2 model persamaan, yaitu persamaan aliran gas-partikel dan persamaan reaksi kimia gasifikasi. Persamaan aliran gas-partikel menggunakan persamaan multiphase particle-in-cell (MP-PIC). Aliran gas diselesaikan dengan persamaan Eulerian sedangkan partikel di selesaikan dengan Lagrangian dimodifikasi dengan model MP-PIC [25], [26].

Reaksi gasifikasi dimodelkan dengan model kinetika reaksi dimana proses tahapan gasifikasi meliputi proses dryng, pirolisis dan proses reaksi heterogen dan proses reaksi homogen. Pada simulasi ini biomassa yang dimasukkan ke reaktor gasifier diasumsikan terdiri dari volatile dan fixed carbon sehingga proses gasifikasi dimulai dari proses devolatilisasi. Proses devolatilisasi menghasilkan char dan gas volatile berupa $\mathrm{CO}, \mathrm{CO}_{2}, \mathrm{H}_{2}, \mathrm{CH}_{4}$. Reaksi berikutnya dimodelkan terjadi reaksi heteregeneuos antara char dengan gas yang berasal uap yang alirkan ke reaktor dan gas species hasil pirolisis yang dan reaksi homogeneus antar gas spesies hasil pirolisis. Char yang tersisa mengalir ke riser dan di dalam riser akan bereaksi dengan $\mathrm{O}_{2}$ dari udara yang mengalir dari bawah distributor riser untuk menghasilkan kalor untuk dikirim ke reaktor gasifier. Detail tiap-tiap tahapan reaksi dijelaskan pada Tabel 3.

Tabel 1 Properti biomassa temperung kelapa

\begin{tabular}{|c|c|c|c|}
\hline \multicolumn{4}{|l|}{ Karakteristik } \\
\hline \multirow[t]{4}{*}{ Proksimate* } & \multicolumn{2}{|c|}{ Moisture (\%) } & - \\
\hline & \multirow{2}{*}{\multicolumn{2}{|c|}{$\begin{array}{l}\text { Ash }(\%) \\
\text { Fixed carbon }(\%)\end{array}$}} & - \\
\hline & & & 19,18 \\
\hline & \multicolumn{2}{|c|}{ Volatile Matter (\%) } & 80,82 \\
\hline \multirow[t]{5}{*}{ Ultimate* } & \multicolumn{2}{|c|}{ Karbon (\%) } & 52,67 \\
\hline & \multicolumn{2}{|c|}{ Hidrogen $(\%)$} & 5,75 \\
\hline & \multicolumn{2}{|c|}{ Nitrogen $(\%)$} & - \\
\hline & \multicolumn{2}{|c|}{ Sulfur $(\%)$} & 0,42 \\
\hline & \multicolumn{2}{|c|}{ Oksigen (\%) } & 41,16 \\
\hline \multicolumn{3}{|c|}{ Nilai Kalor (HHV) (cal/g) } & 4.850 \\
\hline \multirow[t]{2}{*}{ Jari-jari } & \multirow{2}{*}{\multicolumn{2}{|c|}{ minimal $(\mathrm{mm})$}} & 1,00 \\
\hline & & & 2,00 \\
\hline \multirow[t]{2}{*}{ Densitas } & & 2100 \\
\hline & \multicolumn{2}{|c|}{$\begin{array}{l}\text { Fixed Carbon }\left(\mathrm{kg} / \mathrm{m}^{3}\right) \\
\text { Volatile Matter }\left(\mathrm{kg} / \mathrm{m}^{3}\right)\end{array}$} & 1000 \\
\hline \multicolumn{4}{|c|}{ 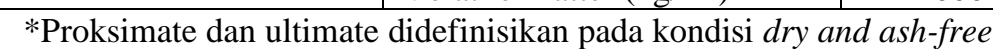 } \\
\hline \multicolumn{4}{|c|}{ Tabel 2 Karakteristik pasir silika } \\
\hline \multicolumn{2}{|c|}{ Karakteristik } & \multicolumn{2}{|l|}{ Nilai } \\
\hline \multirow{3}{*}{\multicolumn{2}{|c|}{$\begin{array}{l}\text { Ukuran jari-jari minimum }(\mathrm{mm}) \\
\text { Ukuran jari-jari maksimum }(\mathrm{mm}) \\
\text { Densitas }\left(\mathrm{kg} / \mathrm{m}^{3}\right)\end{array}$}} & \multirow{3}{*}{\multicolumn{2}{|c|}{$\begin{array}{l}90 \times 10^{-3} \\
180 \times 10^{-3} \\
2650\end{array}$}} \\
\hline & & & \\
\hline & & & \\
\hline
\end{tabular}


Tabel 3 Persamaan reaksi dan kinetika [27], [28], [29]

\begin{tabular}{|c|c|c|}
\hline NO & Persamaan Reaksi & Kinetika \\
\hline R1 & Biomass $\rightarrow$ char + Volatile gas & $r_{1}=0.05 \times T \exp \left(\frac{-5500}{T}\right)[$ Biomass $]$ \\
\hline R2 & $\mathrm{C}+\mathrm{O}_{2} \rightarrow 2 \mathrm{CO}$ & $r_{2}=4.34 \times 10^{7} \alpha_{c} T_{p} \exp \left(\frac{-13590}{T_{p}}\right)\left[O_{2}\right]$ \\
\hline R3 & $\mathrm{C}+\mathrm{H}_{2} \mathrm{O} \leftrightarrow \mathrm{CO}+\mathrm{H}_{2}$ & $\begin{array}{l}r_{3 f}=6.36 m_{c} T_{p} \exp \left(\frac{-22645}{T}\right)\left[H_{2} O\right] \\
r_{3 r}=5.218 \times 10^{-4} m_{c} T_{p}^{2} \exp \left(\frac{-6319}{T}-17.29\right)\left[H_{2}\right][\mathrm{CO}]\end{array}$ \\
\hline R4 & $\mathrm{C}+\mathrm{CO}_{2} \leftrightarrow 2 \mathrm{CO}$ & $\begin{array}{l}r_{4 f}=6.36 m_{c} T_{p} \exp \left(\frac{-22645}{T_{p}}\right)\left[\mathrm{CO}_{2}\right] \\
r_{4 r}=5.218 \times 10^{-4} m_{c} T_{p}^{2} \exp \left(\frac{-2363}{T_{p}}-20.92\right)[\mathrm{CO}]^{2}\end{array}$ \\
\hline R5 & $\mathrm{C}+2 \mathrm{H}_{2} \leftrightarrow \mathrm{CH}_{4}$ & $\begin{array}{l}r_{5 f}=6.838 \times 10^{-3} m_{c} T_{p} \exp \left(\frac{-8078}{T_{p}}-7.078\right)\left[H_{2}\right] \\
r_{5 r}=0.755 m_{c} T_{p}^{0,5} \exp \left(\frac{-13578}{T_{p}}-\right)\left[\mathrm{CH}_{4}\right]^{0,5}\end{array}$ \\
\hline 86 & & $r_{6 f}=7.68 \times 10^{10} \exp \left(\frac{-366409}{T}\right)[\mathrm{CO}]^{0,5}\left[\mathrm{H}_{2} \mathrm{O}\right]$ \\
\hline & & $r_{6 r}=6.4 \times 10^{9} \exp \left(\frac{-39260}{T}\right)\left[\mathrm{H}_{2}\right]^{0,5}\left[\mathrm{CO}_{2}\right]$ \\
\hline R7 & $\mathrm{CO}+0,5 \mathrm{O}_{2} \rightarrow \mathrm{CO}_{2}$ & $r_{7}=1,3 \times 10^{11} \exp \left(\frac{-15155}{T}\right)[\mathrm{CO}]\left[\mathrm{O}_{2}\right]^{0,5}\left[\mathrm{CO}_{2}\right]^{0,5}$ \\
\hline
\end{tabular}

\subsection{Kondisi Awal dan Kondisi Batas}

Kondisi awal (ICs) dan kondisi batas (BCs) diperlukan untuk menyelesaikan persamaan atur simulasi. Kondisi awal dan kondisi batas ditentukan berdasarkan kondisi fisis operasi dual fluidized bed gasifier. Sebelum dioperasikan, gasifier dimodelkan terisi dengan pasir dengan ketinggian $0,3 \mathrm{~m}$, temperatur awalnya $973 \mathrm{~K}$ dan tekanan $101325 \mathrm{~Pa}$. Loop-seal dan l-valve juga terisi pasir dengan temperatur $300 \mathrm{~K}$. Bagian yang tidak terisi pasir diisi oleh udara dengan temperature dan tekanan sesuai dengan bagian masing-masing.

Kondisi batas didefinisikan sebagai perlakuan terhadap bagian terluar domain simulasi. Dalam simulasi DFBG kondisi batas diidentifikasi dengan tekanan, temperatur, kecepatan dan spesies yang masuk maupun yang keluar pada bagian tertentu dari domain komputasi. Parameter kondisi batas dalam simulasi ini meliputi laju pengumpanan masuk biomassa pada screw feeder sebesar $0,0078 \mathrm{~kg} / \mathrm{s}$, temperatur uap yang masuk gasifier sebesar $423 \mathrm{~K}$. Kecepatan uap masuk ke gasifier sebesar 0,15 m/s. Kecepatan udara masuk ke L-valve sebesar 1,57 m/s. Kecepatan udara masuk ke riser $10 \mathrm{~m} / \mathrm{s}$. Temperatur udara masuk ke riser sebesar $1173 \mathrm{~K}$. Uap dengan temperatur $423 \mathrm{~K}$ masuk ke loop-seal dengan kecepatan 0,4 dan 0,5 m/s. 
Simulasi dilakukan dengan variasi temperature pada dinding (thermal wall, t.w ) dengan variasi 873 K, $973 \mathrm{~K}$, dan $1073 \mathrm{~K}$.

\section{HASIL DAN PEMBAHASAN}

Dual Fluidized bed gasifier terdiri dari bagian-bagian terhubung dimana fenomena yang terjadi rumit dan kompleks. Dengan metode simulasi, fenomena tersebut dapat terekam dalam bentuk angka dan kontur sesuai dengan pengaturan data output yang diinputkan. Karakteristik hidrodinamik berupa sirkulasi pasir, dan karakterisik gas hasil gasifikasi berupa distribusi, komposisi, dan yield akan dibahas dalam bagian ini.

\subsection{Pengaruh Thermal Wall terhadap Karaktersitik Hidrodinamika}

Gambar 3 menunjukkan karakteristik hidrodinamika dual fluidized bed gasifier yang dihasilkan tiga variasi simulasi masing-masing (a) untuk t.w $=873 \mathrm{~K}$, (b) untuk t.w=973 K dan (c) untuk t.w $=1073 \mathrm{~K}$. Dari gambar diketahui pada detik ke- 0,4 partikel di loop-seal mulai mengalir ke gasifier. Partikel di L-valve juga mulai mengalir ke riser dalam jumlah yang relative lebih sedikit. Pada detik ini tidak terjadi perbedaan yang signifikan pada karakteristik hidrodinamika di gasifier. Simulasi dengan variasi t.w menghasilkan karaketristik yang hampir sama dimana gelembung mulai terbentuk di gasifier dibagian bawah. Ekspansi bed yang ditunjukkan ketiga hasil simulasi juga identik dimana bed hanya sedikit terekspansi. Pada detik ke-1 partikel dari L-valve sudah mulai mengalir ke riser dimana transport partikel baru mencapai riser bagian bawah. Pada bed gasifier bubble terlihat di bed bagian atas dan bagian bawah. Di detik ke-40, tampak di hasil simulasi t.W $=873 \mathrm{~K}$ terjadi penumpukan partikel dibagian bawah riser. Hal ini berakibat partikel yang keluar dari riser tidak terlihat. Hasil berbeda ditunjukkan oleh simulasi dengan t.w = $973 \mathrm{~K}$ dan $1073 \mathrm{~K}$ dimana pada detik ke-40 partikel sudah tersirkulasi sempurna. Karakteristik hidrodinamika di gasifier pada detik ke-40 menunjukkan perbedaan yang signifikan di karakteristik hidrodinamika yang dihasilkan simulasi dengan t.w $=1073 \mathrm{~K}$ dimana bubble yang terbentuk berukuran lebih besar jika dibandingkan dengan hasil simulasi t. $\mathrm{w}=873 \mathrm{~K}$ dan t.w $=973 \mathrm{~K}$.

Pada detik ke-90 sirkulasi partikel yang dihasilkan simulasi dengan t.w $=873 \mathrm{~K}$ belum sempurna, partikel baru tersirkulasi sampai ke loop-seal. Pada detik ke-90 juga dapat diamati terjadinya ekspansi bed material di gasifier yang ditunjukkan hasil dari simulasi dengan t.w $=973 \mathrm{~K}$ dan t.w $=1073 \mathrm{~K}$. Pada detik ke- 100 dan ke -120 sirkulasi partikel di hasil simulasi loop-seal tampak relatif lebih kecil jika dibandingkan dengan sirkulasi partikel hasil simulasi t.w $=973 \mathrm{~K}$ dan $1073 \mathrm{~K}$. Hal ini disebabkan partikel di simulasi dengan t.w $=873 \mathrm{~K}$ menumpuk di bagian bawah riser.

\subsection{Karakteristik gas hasil simulasi}

Gambar 4 menunjukkan distribusi gas hasil gasifikasi dimana Gambar 4 (a) untuk simulasi dengan t.w $=873 \mathrm{~K}, 6$ (b) untuk simulasi dengan t.w $=973 \mathrm{~K}$ dan 6 (c) untuk simulasi dengan t.w $=1073 \mathrm{~K}$. Dari gambar tampak diketahui distribusi gas hasil simulasi dengan variasi t.w menunjukkan kecenderungan yang sama. Sebagaimana dalam prinsip kerja DFBG dengan agen gasifikasi uap, uap dialirkan ke gasifikasi dari bagian bawah gasifikasi sedangkan biomassa dimasukkan ke gasifier dari screw feeder yang berada di gasifier. Masuknya uap dari bawah gasifier menyebabkan uap terlihat memenuhi daerah bagian bawah bed. Konsentrasi tertinggi gas $\mathrm{CH}_{4}, \mathrm{CO}, \mathrm{CO}_{2}$ dan $\mathrm{H}_{2}$ yang merupakan gas hasil konversi biomassa terlihat di daerah sekitar screw feeder. Di antara daerah dominan gas $\mathrm{CH}_{4}, \mathrm{CO}, \mathrm{CO}_{2}$ dan $\mathrm{H}_{2}$ tampak daerah transisi yang konsenterasi antara uap dengan gas cenderung seimbang. Di daerah sekitar saluran penghubung antara gasifier dengan loop-seal konsenterasi $\mathrm{CH}_{4}, \mathrm{CO}, \mathrm{CO}_{2}$ dan $\mathrm{H}_{2}$ menurun, sedangkan konsentrasi uap terlihat naik.

Hal ini disebabkan oleh masuknya uap dari loop-seal yang mengalir ke gasifier. Perubahan konsenterasi pada gasifier menunjukkan konsenterasi $\mathrm{CH}_{4}, \mathrm{CO}, \mathrm{CO}_{2}$ dan $\mathrm{H}_{2}$ cenderung berkebalikan dengan konsenterasi uap. Pada bagian free board di atas saluran penghubung antara gasifier dengan loop-seal, konsentrasi $\mathrm{CH}_{4}, \mathrm{CO}_{2}, \mathrm{H}_{2}$ terlihat naik. Dari gambar juga dapat diketahui gas hasil gasifikasi tidak mengandung $\mathrm{N}_{2}$ dan $\mathrm{O}_{2}$. 
Konsenterasi gas $\mathrm{CH}_{4}, \mathrm{CO}, \mathrm{CO}_{2}$ dan $\mathrm{H}_{2}$ tertinggi yang terbentuk di daerah dekat masuk biomassa menunjukkan proses pirolisis sebagai awal proses gasifikasi terjadi sesaat setelah biomassa masuk ke gasifier. Karena konsenterasi gas $\mathrm{CH}_{4}, \mathrm{CO}, \mathrm{CO}_{2}$ naik konsenterasi uap turun. Menurunnya konsentrasi uap juga diakibatkan oleh reaksi heterogen antara uap $\left(\mathrm{H}_{2} \mathrm{O}\right)$ dalam fase gas yang bereaksi dengan karbon (padat) dalam reaksi water-gas or steam yang menghasilkan $\mathrm{CO}$ dan $\mathrm{H}_{2}$. Di bagian atas gasifier, distribusi gas $\mathrm{CH}_{4}, \mathrm{CO}, \mathrm{CO}_{2}$ dan $\mathrm{H}_{2}$ menunjukkan kecenderungan yang berbeda-beda. Kenaikan konsenterasi $\mathrm{CO}_{2}$ tampak lebih besar jika dibandingkan dengan kenaikan konsentrasi gas yang lainnya. Sedangkan kenaikan gas CO tampak paling kecil. Hal ini menunjukkan reaksi homogen antara uap dengan gas hasil pirolisis di bagian atas gasifier didominasi reaksi shift reaction yaitu reaksi antara $\mathrm{CO}$ dengan uap yang menghasilkan $\mathrm{CO}_{2}$ dan $\mathrm{H}_{2}$.

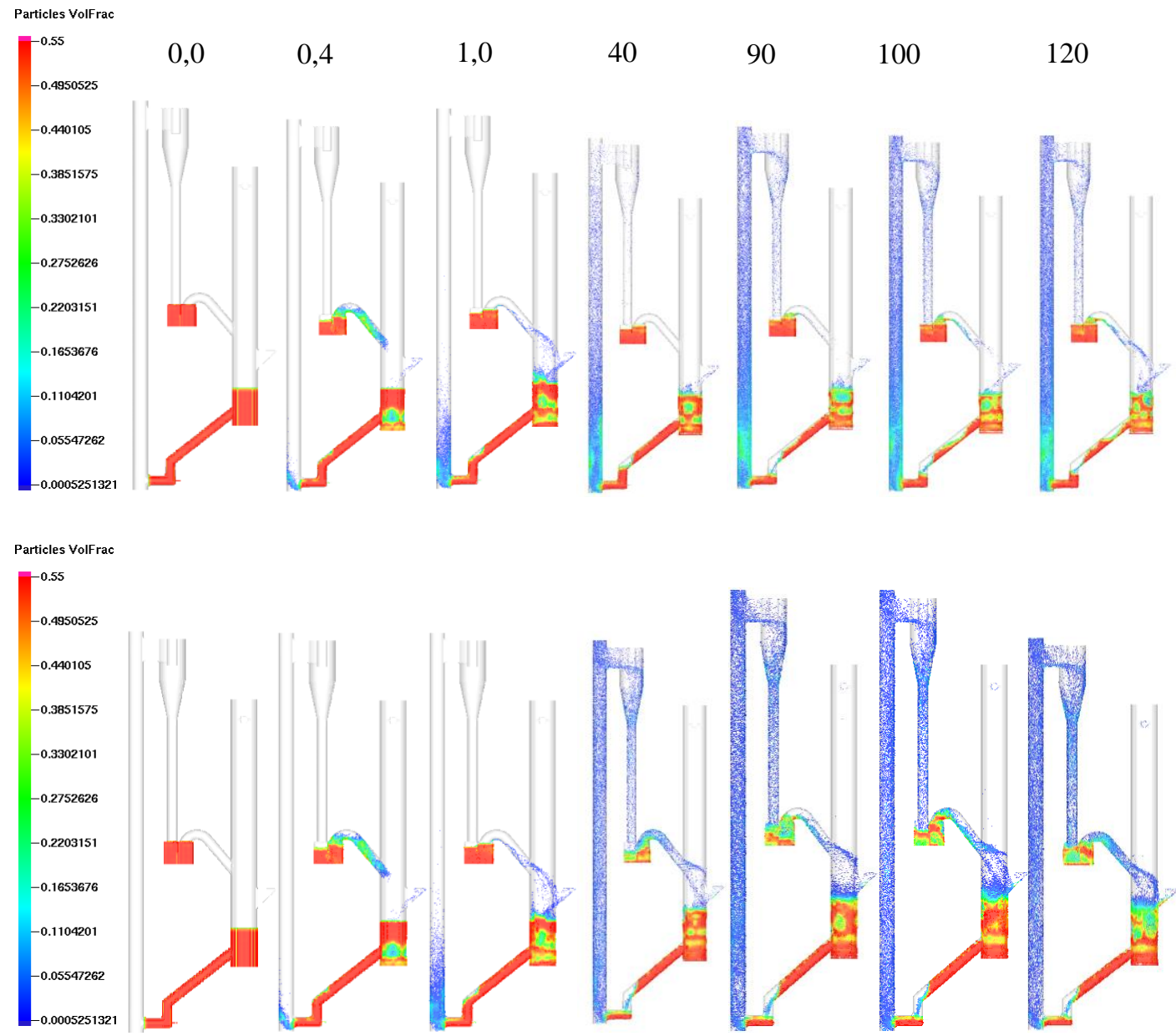

(a)

(b) 


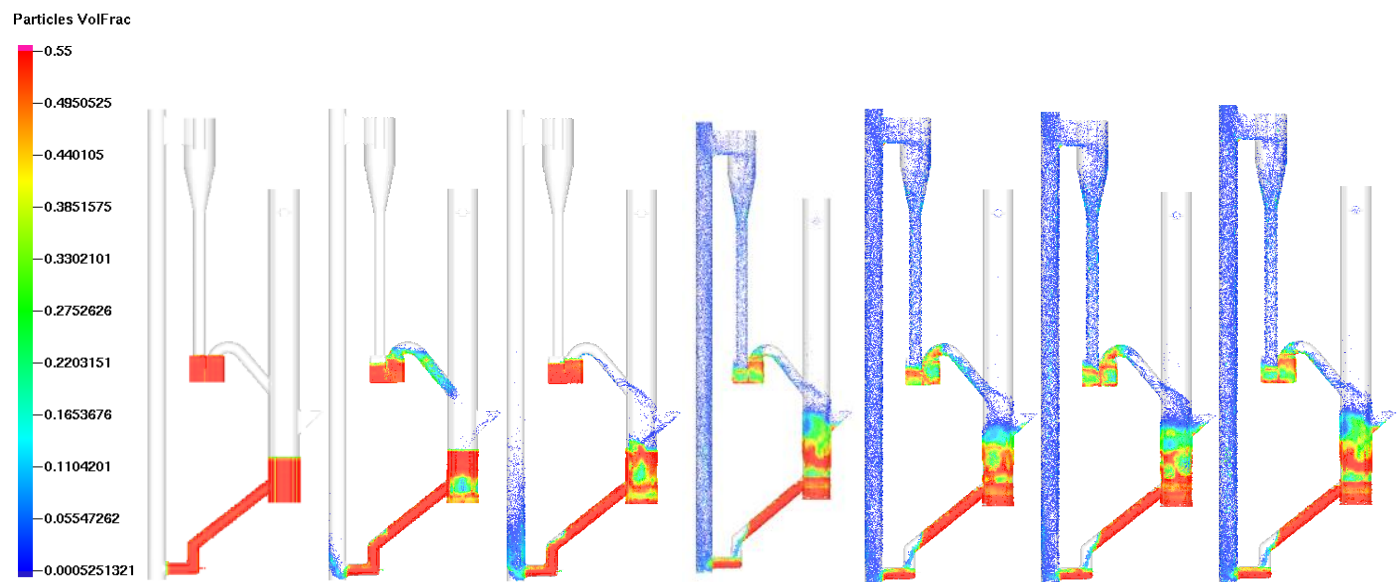

(c)

Gambar 3 Karakteristik Hidrodinamika (a) t.w $=873$ K, (b) t.w= 973 K dan (c) t.w=1073 K

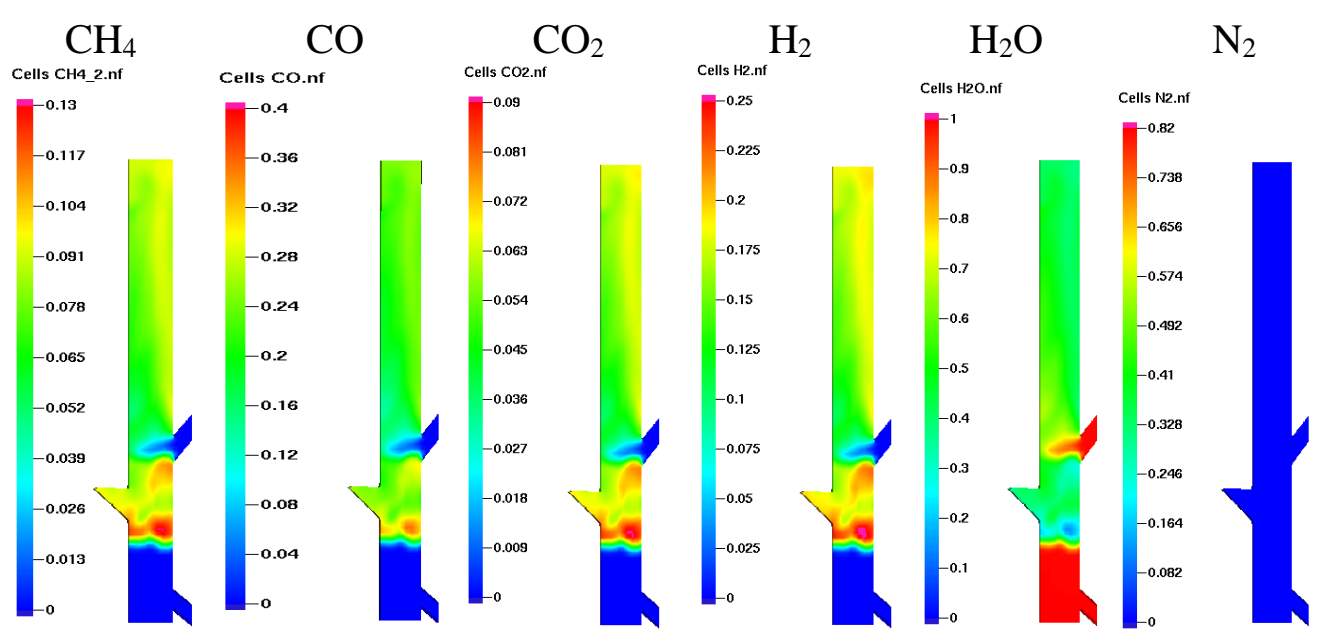

(a)

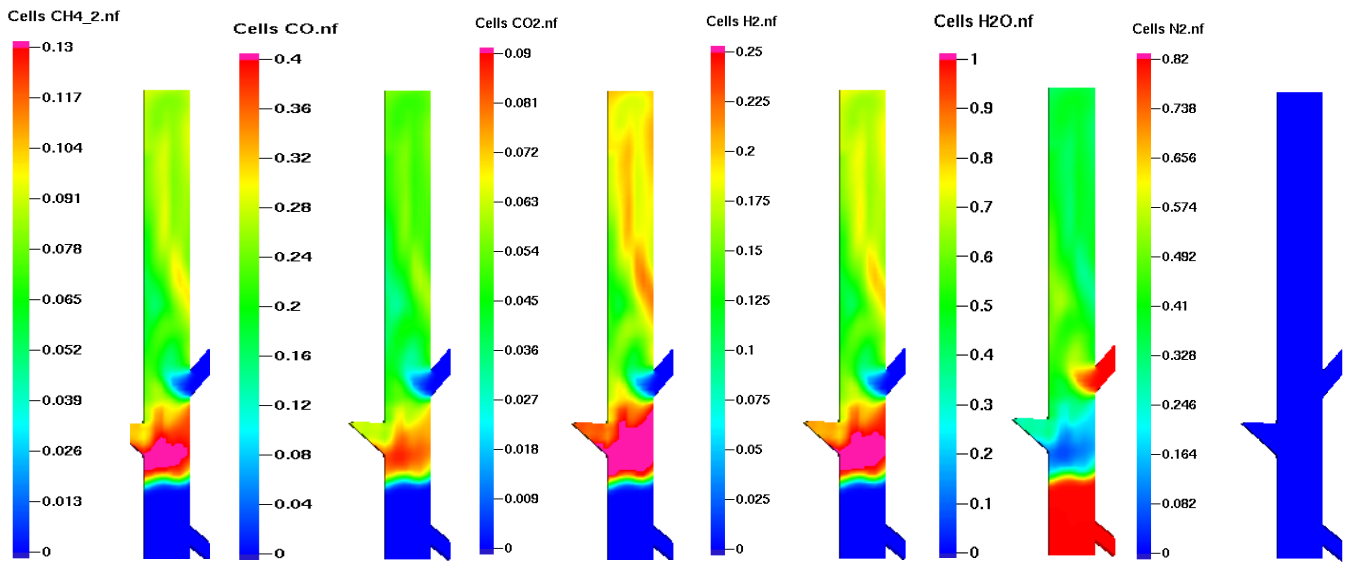




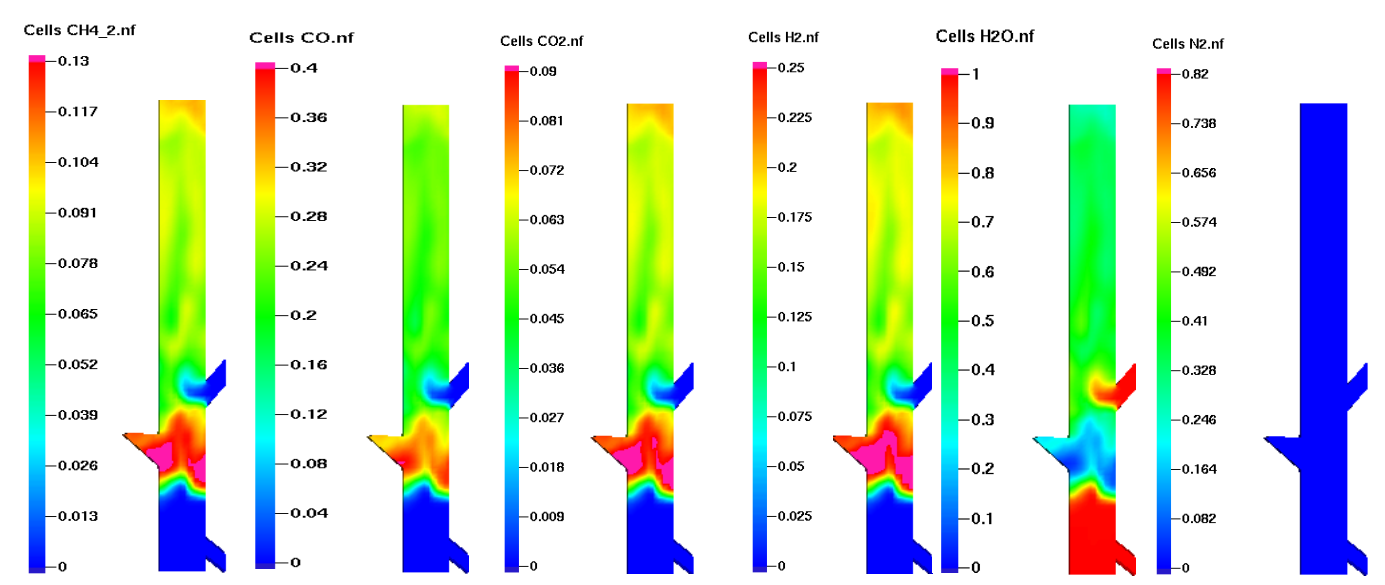

Gambar 4 Karakteristik Hidrodinamika (a) t.w $=873$ K, (b) t.w= 973 K dan (c) t.w=1073 K

Sebagaimana diketahui temperatur adalah salah satu faktor yang mempengaruhi pembentukan gas pada pirolisis. Dalam gambar terlihat konsentrasi gas yang dihasilkan simulasi dengan t.w $=873 \mathrm{~K}$ tampak lebih rendah jika dibandingkan dengan konsenterasi gas yang dihasilkan simulasi dengan t.w $=973 \mathrm{k}$ dan $1073 \mathrm{~K}$. Pengaruh besarnya t.w terhadap distribusi gas tampak pada pembentukan gas di atas gasifier dimana kenikan konsentrasi gas terjadi dibagian dekat dinding reaktor yang memiliki temperatur lebih tinggi jika dibanding dengan bagian tengah gasifier.

\section{Komposisi Gas}

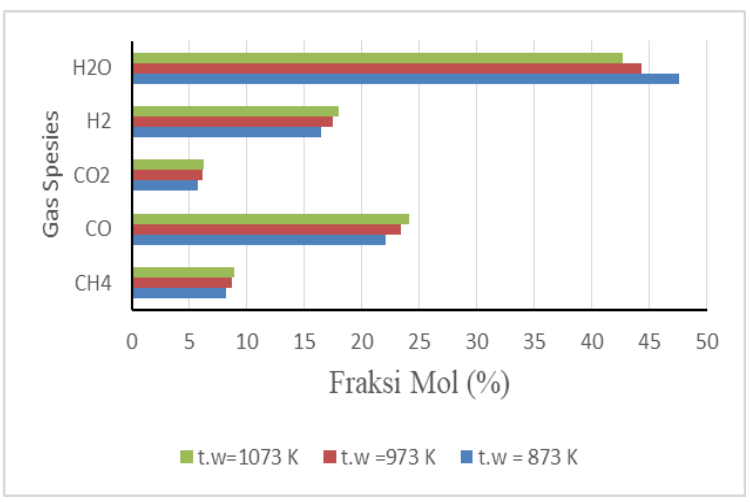

Gambar 5 Komposisi Gas Hasil simulasi (gas basah).

Gambar 5 menunjukkan komposisi gas dalam bentuk fraksi mol hasil simulasi dengan t.w = $873 \mathrm{~K}, 973 \mathrm{~K}$ dan $1073 \mathrm{~K}$. Data diambil dari transien poin spesies gas yang dipasang di daerah saluran keluar gas hasil gasifikasi. Dari gambar diketahui untuk semua variasi simulasi komposisi gas dengan komposis tertinggi adalah $\mathrm{CO}$, diikuti $\mathrm{H}_{2}, \mathrm{CH}_{4}$ dan $\mathrm{CO}_{2}$. Simulasi dengan t.w=873 K menghasilkan komposisi gas dengan komposisi 22,05\% CO, 16, $45 \% \mathrm{H}_{2}, 8,20 \% \mathrm{CH}_{4}$, dan 5,77 $\% \mathrm{CO}_{2}$. Komposisi ini berubah saat t.w dinaikkan menjadi $973 \mathrm{~K}$ dengan komposisi sebagai berikut 23,40\% $\mathrm{CO}, 17,45 \% \mathrm{H}_{2}, 8,70 \% \mathrm{CH}_{4}$, dan $6,12 \% \mathrm{CO}_{2}$. Dengan menghitung dalam prosentase perubahan komposisi yang terjadi pada masing-masing spesies, gas mengalami 
kenaikan sebesar 5,78\% saat t.w dinaikkan dari $873 \mathrm{~K}$ menjadi $973 \mathrm{~K}$. Pada simulasi dengan t.w $=1073 \mathrm{~K}$ komposisi gas yang dihasilkan sebagai berikut $24,07 \% \mathrm{CO}, 17,96 \% \mathrm{H}_{2}, 8,96 \% \mathrm{CH}_{4}$, dan $6,30 \% \mathrm{CO}_{2}$. Nilai ini lebih besar 2,8 \% dari komposisi gas yang dihasilkan pada simulasi dengan t.w $=973 \mathrm{~K}$.

Perbandingan $\mathrm{H}_{2} / \mathrm{CO}$ pada masing-masing simulasi menunjukkan angka yang sama yaitu 0,75. Dominannya komposisi CO pada gas yang dihasilkan disebabkan proses awal gasifikasi terjadi pada temperatur rendah.Komposisi $\mathrm{H}_{2} \mathrm{O}$ untuk masing-masing hasil simulasi menunjukkan angka 47,53 \% untuk simulasi dengan t. $\mathrm{w}=873 \mathrm{~K}, 44,32 \%$ untuk t.w $=973 \mathrm{~K}$ dan 42,72\% untuk t.w $=1073 \mathrm{~K}$. Kandungan uap yang relatif tinggi ini disebabkan adanya uap yang masuk dari loopseal ke gasifier bersama dengan pasir. Kenaikan t.w dari 873 K menjadi 973 K menyebabkan konversi uap naik sebesar 7,23\%, sedangkan dari $973 \mathrm{~K}$ ke $1073 \mathrm{~K}$ konversi uap naik sebesar $3,76 \%$.

Tabel 4 Lower Heating Value (LHV)

\begin{tabular}{c|c}
\hline t.w $(\mathbf{K})$ & LHV $\left(\mathbf{M J} / \mathbf{n m}^{\mathbf{3}}\right)$ \\
\hline 873 & 7.50 \\
973 & 7.96 \\
1073 & 8.19 \\
\hline
\end{tabular}

Tabel 4 menunjukkan nilai kandungan kalor LHV gas hasil simulasi. Dari tabel 3 diketahui peningkatan temperatur dinding menyebabkan kandungan kalor gas meningkat. Peningkatan ini linier dengan peningkatan komposisi $\mathrm{CO}, \mathrm{H}_{2}$ dan $\mathrm{CH}_{4}$.

\section{Yield Gas}

Gambar 6 menunjukkan yield gas hasil simulasi. Data diambil dari jumlah total gas yang melewati flux plane yang dipasang pada bagian atas gasifier selama simulasi. Dari gambar diketahui yield tertinggi untuk masing-masing simulasi ditunjukkan gas $\mathrm{CO}$, disusul $\mathrm{CO}_{2}, \mathrm{CH}_{4}$ dan $\mathrm{H}_{2}$. Kenaikan t.w yield spesies gas meningkat. Kenaikan t.w dari $873 \mathrm{~K}$ menjadi $973 \mathrm{~K}$ menyebabkan yield $\mathrm{CO}$ naik dari 0,226 menjadi 0,283 pada simulasi dengan $\mathrm{t} . \mathrm{w}=973 \mathrm{~K}$ dan naik menjadi 0,344 pada simulasi dengan t.w $=1073 \mathrm{~K}$. Yield $\mathrm{CO}_{2}$ juga menunjukkan kenaikan saat t.w naik, dimana saat $\mathrm{t} . \mathrm{w}=873 \mathrm{~K}$ yield $\mathrm{CO}_{2}$ sebesar 0,093 berubah menjadi 0,116 saat t.w $=973 \mathrm{~K}$ dan naik menjadi 0,141 saat t.w $=1073 \mathrm{~K}$. Yield $\mathrm{CH}_{4}$ naik dari 0,048 menjadi 0,060 saat t.w naik dari $873 \mathrm{~K}$ menjadi $973 \mathrm{~K}$ dan berubah menjadi 0,073 saat t.w berubah menjadi 0,073 . Yield gas $\mathrm{H}_{2}$ pada simulasi dengan t. $\mathrm{w}=873 \mathrm{~K}$ sebesar 0,012 dan naik menjadi 0,015 pada simulasi t. $\mathrm{w}=973$ $\mathrm{K}$ dan naik menjadi 0,018 saat t.w berubah menjadi $1073 \mathrm{~K}$. Kenaikan t.w dari $873 \mathrm{~K}$ menjadi 973 K menyebabkan yield gas naik sebesar 20,4\%, sedangkan perubahan t.w dari $973 \mathrm{~K}$ ke $1073 \mathrm{~K}$ menyebabkan kenaikan yield sebesar $17.5 \%$. 


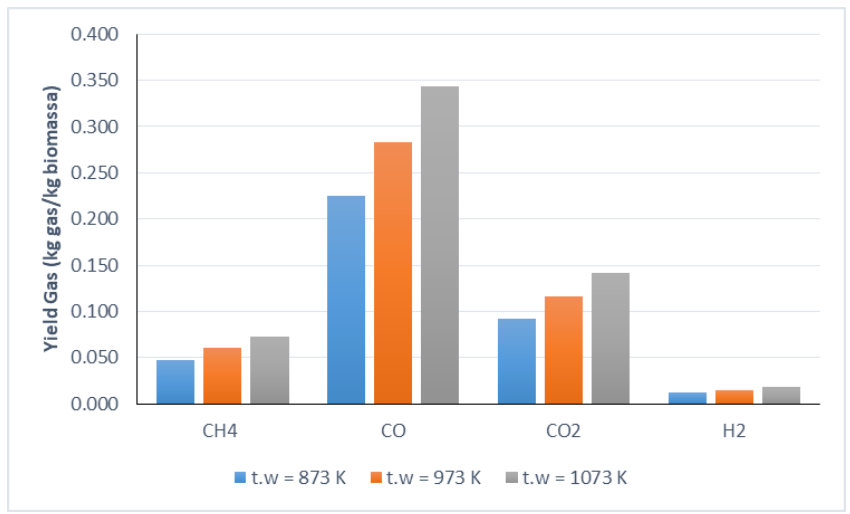

Gambar 6 Yield Gas

\section{KESIMPULAN}

Simulasi berbasis computational Particle Fluid dynamics (CPFD) pada Dual Fluidized bed gasifier berbahan bakar tempurung kelapa dengan agen gasifikasi uap telah dilakukan. Simulasi dilakukan untuk mengetahui pengaruh thermal wall (t.w) pada dinding gasifier terhadap karakteristik hidrodinamika dan karakteristik syngas. Thermal wall (t.w) yang digunakan di simulasi ini sebesar $873 \mathrm{~K}, 973 \mathrm{~K}$ dan $1073 \mathrm{~K}$.

Karakteristik hidrodinamika pada masing-masing komponen DFBG tampak dapat tervisualisasi dengan baik, dimana masing-masing komponen dapat beroperasi sesuai dengan rezim yang direncanakan yaitu gasifier dan loop-seal dalam mode bubbling, riser dalam mode fast fluidization dan L-valve pada mode fixed bed. Pengaruh Thermal wall terlihat pada karakteristik hidrodinamika DFBG, dimana simulasi dengan t.w $=873 \mathrm{~K}$ menghasilkan penumpukan partikel di bagian bawah riser.

Komposisi dan distribusi gas yang dihasilkan oleh simulasi dengan variasi t.w menunjukkan kecenderungan yang sama dimana gas yang dihasilkan didominasi oleh gas $\mathrm{CO}$, disusul $\mathrm{H}_{2}, \mathrm{CO}_{2}$ dan $\mathrm{CH}_{4}$. Pembentukan gas berawal di daerah biomassa masuk dan komposisi akan berubah seiring dengan ketinggian reaktor. Pengaruh t.w terhadap karakteristik gas tampak pada naiknya jumlah uap yang terkonversi menjadi gas $\mathrm{CO}, \mathrm{H}_{2}, \mathrm{CO}_{2}$ dan $\mathrm{CH}_{4}$ saat t.w naik dimana uap yang terkonversi menjadi gas naik sebesar 7,23 \% saat t.w naik dari $873 \mathrm{~K}$ menjadi $973 \mathrm{~K}$ dan naik sebesar 3,76\% saat t.w berubah dari $973 \mathrm{~K}$ menjadi $1073 \mathrm{~K}$. Kenaikan ini terdistribusi ke kenaikan komposisi gas $\mathrm{CO}, \mathrm{H}_{2}, \mathrm{CO}_{2}$ dan $\mathrm{CH}_{4}$ seragam sebesar 5,78 \% saat t.w berubah dari 873 $\mathrm{K}$ ke $973 \mathrm{~K}$ dan $2,8 \%$ saat t.w naik dari $973 \mathrm{~K}$ ke $1073 \mathrm{~K}$. Thermal wall juga berpengaruh signifikan terhadap yield gas yang dihasilkan dimana t.w naik akan menyebabkan yield gas naik.

\section{PERSANTUNAN}

Penulis mengucapkan terima kasih kepada Lembaga pengelola Dana Pendidikan (LPDP) Kementerian Keuangan Republik Indoneisa yang telah memberi beasiswa kepada penulis melauli skem Beasiswa Unggulan Dosen Indonesia Dalam Negeri (BUDI-DN) tahun 2016.

\section{DAFTAR PUSTAKA}

[1] www.bps.go,id

[2] A. Lappas and E. Heracleous, Production of biofuels via Fischer-Tropsch synthesis: Biomass-to-liquids. Biomass-to-liquids. Elsevier Ltd, 2016.

[3] S. S. Ail and S. Dasappa, 'Biomass to liquid transportation fuel via Fischer Tropsch synthesis - Technology review and current scenario', Renew. Sustain. Energy Rev., vol. 58, pp. 267-286, 2016.

[4] F. Vidian, 'Gasifikasi Tempurung Kelapa Menggunakan Updraft Gasifier pada Beberapa 
Variasi Laju Alir Udara Pembakaran’, J. Tek. MESIN, vol. 10, pp. 88-93, 2008.

[5] I. G. H. Gunawan, M. Sucipta, I. Nyoman, and S. Winaya, 'Analisis Performansi Reaktor Gasifikasi Updraft Dengan Bahan Bakar Tempurung Kelapa', vol. 1, no. 2, pp. 28-34, 2015.

[6] G. Venkatesh, P. R. Reddy, and S. Kotari, 'ScienceDirect Generation of producer gas using coconut shells and sugar cane bagasse in updraft gasifier', Mater. Today Proc., vol. 4, no. 8, pp. 9203-9209, 2017.

[7] M. Senthil and S. Vivekanandan, 'Effect of Processing Parameters on the Biomass Gasification of Coconut Shell', no. 7, pp. 388-397, 2016.

[8] M. K. Karmakar and A. B. Datta, 'Hydrodynamics of a dual fluidized bed gasifier', Adv. Powder Technol., vol. 21, no. 5, pp. 521-528, 2010.

[9] S. Shrestha, B. S. Ali, B. M. Jan, M. Diana, B. Hamid, and K. El Sheikh, 'Hydrodynamic characteristics in cold model of dual fl uidized bed gasi fi ers', vol. 286, pp. 246-256, 2015.

[10] M. Tzeng, W. Saw, and S. Pang, 'Particuology Effect of fluidizing velocity on gas bypass and solid fraction in a dual fluidized bed gasifier and a cold model', Particuology, vol. 18, pp. 58-65, 2015.

[11] S. Kern, C. Pfeifer, and H. Hofbauer, 'Gasification of lignite in a dual fluidized bed gasifier - Influence of bed material particle size and the amount of steam', Fuel Process. Technol., vol. 111, pp. 1-13, 2013.

[12] K. Göransson, U. Söderlind, and W. Zhang, 'Experimental test on a novel dual fluidised bed biomass gasifier for synthetic fuel production', Fuel, vol. 90, no. 4, pp. 1340-1349, 2011.

[13] W. Saw, H. Mckinnon, I. Gilmour, and S. Pang, 'Production of hydrogen-rich syngas from steam gasification of blend of biosolids and wood using a dual fluidised bed gasifier', Fuel, vol. 93, pp. 473-478, 2012.

[14] S. Kern, C. Pfeifer, and H. Hofbauer, 'Gasification of wood in a dual fluidized bed gasifier: Influence of fuel feeding on process performance', Chem. Eng. Sci., vol. 90, pp. 284-298, 2013.

[15] N. Aklis, T. A. Rohmat, and H. Saptoadi, 'Mapping of Circulating Rate to Determine Nonmechanic Valve Operation in Dual Fluidized Bed Gasifier Cold Flow Model', Proceedings of the 6th International Conference and Exhibition on Sustainable Energy and Advanced Materials, Lecture Notes in Mechanical Engineering, pp. 745-754, 2020.

[16] W. Doherty, A. Reynolds, and D. Kennedy, 'Aspen Plus Simulation of Biomass Gasification in a Steam Blown Dual Fluidised Bed', 2013.

[17] L. Shen, Y. Gao, and J. Xiao, 'Simulation of hydrogen production from biomass gasification in interconnected fluidized beds', Biomass and Bioenergy, vol. 32, no. 2, pp. 120-127, 2008.

[18] L. Yan, C. J. Lim, G. Yue, B. He, and J. R. Grace, 'One-dimensional modeling of a dual fluidized bed for biomass steam gasification', Energy Convers. Manag., vol. 127, pp. 612622, 2016.

[19] W. K. H. Ariyaratne and M. C. Melaaen, 'CFD Approaches for Modeling Gas-Solids Multiphase Flows - A Review 2 Basic CFD Approaches for', pp. 680-686, 2016.

[20] D. M. Snider, S. M. Clark, and P. J. O. Rourke, 'Eulerian - Lagrangian method for threedimensional thermal reacting flow with application to coal gasifiers', Chem. Eng. Sci., vol. 66, no. 6, pp. 1285-1295, 2011.

[21] S. Kraft, F. Kirnbauer, and H. Hofbauer, 'Particuology Influence of drag laws on pressure and bed material recirculation rate in a cold flow model of an $8 \mathrm{MW}$ dual fluidized bed system by means of CPFD', Particuology, vol. 36, no. 2018, pp. 70-81, 2020.

[22] H. Liu, R. J. Cattolica, and R. Seiser, 'Operating parameter effects on the solids circulation rate in the CFD simulation of a dual fluidized-bed gasification system', Chem. Eng. Sci., 
vol. 169, pp. 235-245, 2017.

[23] H. Liu, R. J. Cattolica, R. Seiser, and C. hsien Liao, 'Three-dimensional full-loop simulation of a dual fluidized-bed biomass gasifier', Appl. Energy, vol. 160, pp. 489-501, 2015.

[24] S. Kraft, F. Kirnbauer, and H. Hofbauer, 'CPFD simulations of an industrial-sized dual fluidized bed steam gasification system of biomass with $8 \mathrm{MW}$ fuel input', Appl. Energy, 2017.

[25] M. J. Andrews and P. J. O'rourke, 'The Multiphase Particle-In-Cell (MP-IC) Method fro Dense Particulate Flows', Int. J. Multiph. Flow, vol. 22, no. 2, pp. 379-402, 1996.

[26] S. Pannala, M. Syamlal, and T. O'Brien, Computational Gas-Solids Flows and Reacting Systems: Theory, Methods and Practice. 2010.

[27] F. Bustamante et al., 'High-Temperature Kinetics of the Homogeneous Reverse WaterGas Shift Reaction', AIChE J., vol. 50, no. 5, pp. 1028-1041, 2004.

[28] P. G. Prusakov and L. V Sergeeva, 'Physical and Thermody-namic Properties of Aliphatic Alcohols', J. Phys. Chem. Ref. Zubarev, vol. 47, no. 5, p. 1443, 1974.

[29] M. Syamlal and L. A. Bissett, 'METC Gasifier Advanced Simulation ( MGAS ) model METC-Gasifier Advanced Simulation ( MGAS ) Model Technical Note by EG \& G Washington Analytical Services Center, Inc . and U . S . Department of Energy Morgantown Energy Technology Center Morgantown, West', West Virginia, 1992. 